\title{
ESTIMASI PRODUKSI JAGUNG (Zea Mays L.) DENGAN MENGGUNAKAN CITRA SENTINEL 2A DI SEBAGIAN WILAYAH KABUPATEN JENEPONTO PROVINSI SULAWESI SELATAN
}

\author{
Laode Muhamad Irsan*, Sigit Heru Murti, dan Prima Widayani \\ Program Pascasarjana Penginderaan Jauh \\ Universitas Gadjah Mada
}

Submitted: 11-07-2018; Revised: 21-09-2018; Accepted: 25-09-2018

\begin{abstract}
Production is a real benchmark in successful crop management which is the most important output economically. Currently, estimation of corn production are generally done by conventional way through field surveys. This conventional way requires a high cost and a long time. Appropriate agricultural management requires precise and accurate information and data to increase production and economic benefits. Data obtained from Sentinel $2 \mathrm{~A}$ remote sensing satellite is potential to be used in assessment of corn production estimation. The purpose of this research is to perform land use mapping and corn production estimation by using spectral approach. Estimated data were obtained from Sentinel $2 A$ image by mapping land use and modeling of vegetation index (NDVI, SAVI, MSAVI, TSAVI, EVI, and ARVI) then comparing it with data of corn production in the field. The result of data analysis shows land use mapping using Sentinel $2 A$ image has confidence level of $91 \%$. Calculation of production estimation can show the accuracy of $74 \%$ with RMSE 0.69 . The highest correlation is estimated production with EVI index model with regression correlation equal to $74 \%$ which shows strong correlation on both variables. Estimated production of corn in 2017 in Jeneponto Regency is 178,660.69 tons.
\end{abstract}

Keywords: Production Estimation; Remote Sensing; Sentinel 2A Image; Vegetation Index.

\begin{abstract}
ABSTRAK
Produksi merupakan tolok ukur yang riil dalam keberhasilan pengelolaan tanaman yang merupakan output terpenting secara ekonomis. Saat ini perkiraan produksi jagung umumnya dilakukan dengan cara konvensional yaitu melalui survei lapangan. Cara konvensional ini membutuhkan biaya tinggi dan waktu yang lama. Manajemen pertanian yang tepat memerlukan informasi atau data yang tepat dan akurat sehingga dapat meningkatkan produksi dan keuntungan ekonomi. Data satelit penginderaan jauh Sentinel 2A sangat berpotensi untuk dipergunakan dalam kajian estimasi produksi jagung. Tujuan dari penelitian ini yaitu untuk melakukan pemetaan penggunaan lahan dan estimasi produksi jagung dengan menggunakan pendekatan spektral. Estimasi data diperoleh dari Citra sentinel 2A dengan melakukan pemetaan penggunaan lahan dan pemodelan indeks vegetasi (NDVI, SAVI, MSAVI, TSAVI, EVI, dan ARVI) yang kemudian dibandingkan dengan data jumlah produksi jagung di lapangan. Hasil analisis data menunjukan pemetaan penggunaan lahan dengan menggunakan citra Sentinel 2A memiliki tingkat kepercayaan 90,01\%. Perhitungan estimasi produksi mampu menunjukan akurasi sebesar 74\% dengan RMSE 0,69. Korelasi tertinggi yakni estimasi produksi dengan model indeks EVI dengan korelasi regresi sebesar $74 \%$ yang menunjukan korelasi kuat pada kedua variabel tersebut.
\end{abstract}

*Corresponding author: laodemuhamadirsan93@gmail.com

Copyright@2019 THE AUTHOR(S). This article is distributed under a Creative Commons Attribution-Share Alike 4.0 International license. Jurnal Teknosains is published by the Graduate School of Universitas Gadjah Mada. 
Estimasi jumlah produksi total jagung tahun 2017 di Kabupaten Jeneponto yaitu sebanyak $178.660,69$ ton.

Kata Kunci: Citra Sentinel 2A; Estimasi Produksi; Indeks Vegetasi; Penginderaan Jauh.

\section{PENGANTAR}

Jagung (Zea mays L.) adalah tanaman semusim yang merupakan salah satu tanaman pangan penghasil karbohidrat penting di dunia, selain gandum dan padi (Kementerian Pertanian, 2015). Jagung mempunyai peran strategis dalam perekonomian nasional, mengingat fungsinya yang multiguna. Jagung dapat dimanfaatkan untuk pangan, pakan, dan bahan baku industri. Kementerian pertanian mencatat sektor pertanian memberikan kontribusi lebih terhadap perekonomian nasional pada tahun 2014 hingga 2016. Hal ini terlihat dari nilai Produk Domestik Bruto (PDB) pertanian atas dasar harga berlaku 2014 sebesar Rp1.410 triliun, 2015 naik menjadi Rp1.556 triliun dan 2016 menjadi Rp1.669 triliun. Rata-rata kontribusi sektor pertanian tiga tahun terakhir $13,4 \%$ dan pertumbuhan $3,75 \%$ pertahun. Kontribusi terbesar dari komoditas tanaman pangan yaitu padi, jagung, dan kedelai (Kementerian Pertanian, 2017).

Produksi merupakan tolok ukur yang riil dalam keberhasilan pengelolaan tanaman yang merupakan output terpenting secara ekonomis. Produktivitas tanaman sangat bervariasi sesuai dengan kondisi lingkungan (iklim, kondisi lahan), kondisi genetik (bahan tanaman dan umur tanaman), dan interaksi di antara keduanya yang berupa pelaksanaan kultur teknis manajemen (Weng, 1985 dalam Harahap dkk, 2000). Perdebatan masalah data produksi jagung terus berlangsung, masing-masing pemangku kepentingan punya argumentasi sendiri sesuai dengan kepentingannya. Saat ini perkiraan produksi Jagung umumnya dilakukan dengan cara konvensional yaitu melalui survei lapangan. Cara konvensional ini membutuhkan biaya tinggi dan waktu yang lama (Jin dkk, 2015). Manajemen pertanian yang tepat memerlukan informasi atau data yang tepat dan akurat sehingga dapat meningkatkan produksi dan keuntungan ekonomi (Skakun dkk, 2017).

Mengacu pada konsep kecepatan, akurasi, kemutakhiran, dan konsistensi data atau informasi untuk suatu kegiatan atau perencanaan dan pengambilan keputusan yang tepat, maka pemanfaatan teknologi penginderaan jauh dan sistem informasi geografis di bidang pertanian adalah sangat mendukung (Murti, 2014). Pemanfaatan citra penginderaan jauh untuk estimasi produksi pertanian khususnya jagung masih jarang dilakukan di Indonesia. Saat ini kajian tentang estimasi produksi jagung sering dilakukan oleh negara-negara Amerika, Argentina, Afrika Selatan, Polandia, Hungaria, Kazakstan, India, China, dan Meksiko (Soria dkk., 2004).

Penginderaan jauh dalam kaitannya dengan studi vegetasi khususnya dalam bidang pertanian dapat digunakan untuk mengetahui kondisi, jumlah dan ketersediaan tanaman dalam kaitannya dengan mengetahui (memprediksi) hasil produksi dari suatu tanaman. Penginderaan jauh merupakan sumber informasi penting untuk manajemen produksi pertanian dan penilaian ketersediaan serta permintaan (Aronoff, 2005).

Ketersediaan data penginderaan jauh saat ini sangat banyak, salah satu citra yang popular yaitu citra Sentinel 2A memiliki resolusi sedang yang dapat diperoleh dengan mudah dan gratis. Data satelit penginderaan jauh ini sangat berpotensi untuk dipergunakan dalam kajian kondisi tanaman pertanian dan sekitarnya, dengan informasinya terbaru dan akurat serta cakupannya luas dapat membantu dalam melakukan kajian tentang estimasi produksi pertanian jagung melalui indeks vegetasi yang diekstrak dari data pantulan spektral untuk membangun model (Viktor, 2015). Pada terapannya citra penginderaan jauh ini memberikan kemudahan baik dari pengumpulan data yang cepat dan murah, serta memungkinkan pengumpulan data pada medan yang sulit dijangkau secara terestrial (Howard, 1991). Berdasarkan latar belakang dan uraian di atas, maka rumusan masalahnya sebagai berikut: 
1. Estimasi produksi dibidang pertanian jagung masih berdasarkan perhitungan kovensional yaitu survei langsung di lapangan. Data citra penginderaan jauh seperti citra Sentinel 2A belum banyak digunakan untuk interpretasi penggunaan lahan pertanian khususnya tanaman jagung.

2. Karakteristik wilayah suatu lahan berbedabeda yang tentu berpengaruh terhadap jumlah produksi yang dihasilkan. Untuk itu, diperlukan pendekatan yang berbeda pula pada setiap kondisi lahan yang ada salah satunya adalah pendekatan spektral dengan model indeks vegetasi.

Berdasarkan latar belakang dan perumusan masalah yang dikemukakan di atas, maka secara umum sebagai berikut: (1) Mengkaji kemampuan citra penginderaan jauh, khususnya Sentinel 2A untuk interpretasi penggunaan lahan yang ditanami tanaman jagung dan (2) Mendapatkan jumlah estimasi dan peta sebaran produksi jagung melalui pendekatan spektral berdasarkan indeks vegetasi.

Lokasi penelitian ini dilakukan di Kabupaten Jeneponto terletak di bagian selatan dari wilayah Provinsi Sulawesi Selatan. Secara geografis Kabupaten Jeneponto terletak antara $5^{\circ} 16^{\prime} 13^{\prime \prime}-5^{\circ} 39^{\prime} 35^{\prime \prime}$ lintang selatan dan $12^{\circ}$ $40^{\prime} 19^{\prime \prime}$ - $12^{\circ} 7^{\prime} 31^{\prime \prime}$ bujur timur. Berbatasan dengan Kabupaten Gowa dan Takalar di sebelah utara, Kabupaten Bantaeng di sebelah timur, Kabupaten Takalar sebelah barat dan laut Flores di sebelah selatan. Wilayah penelitian ini mencangkup empat kecamatan yaitu Kecamatan Bangkala Barat, Bangkala, Bontoramba, dan Tamalatea.

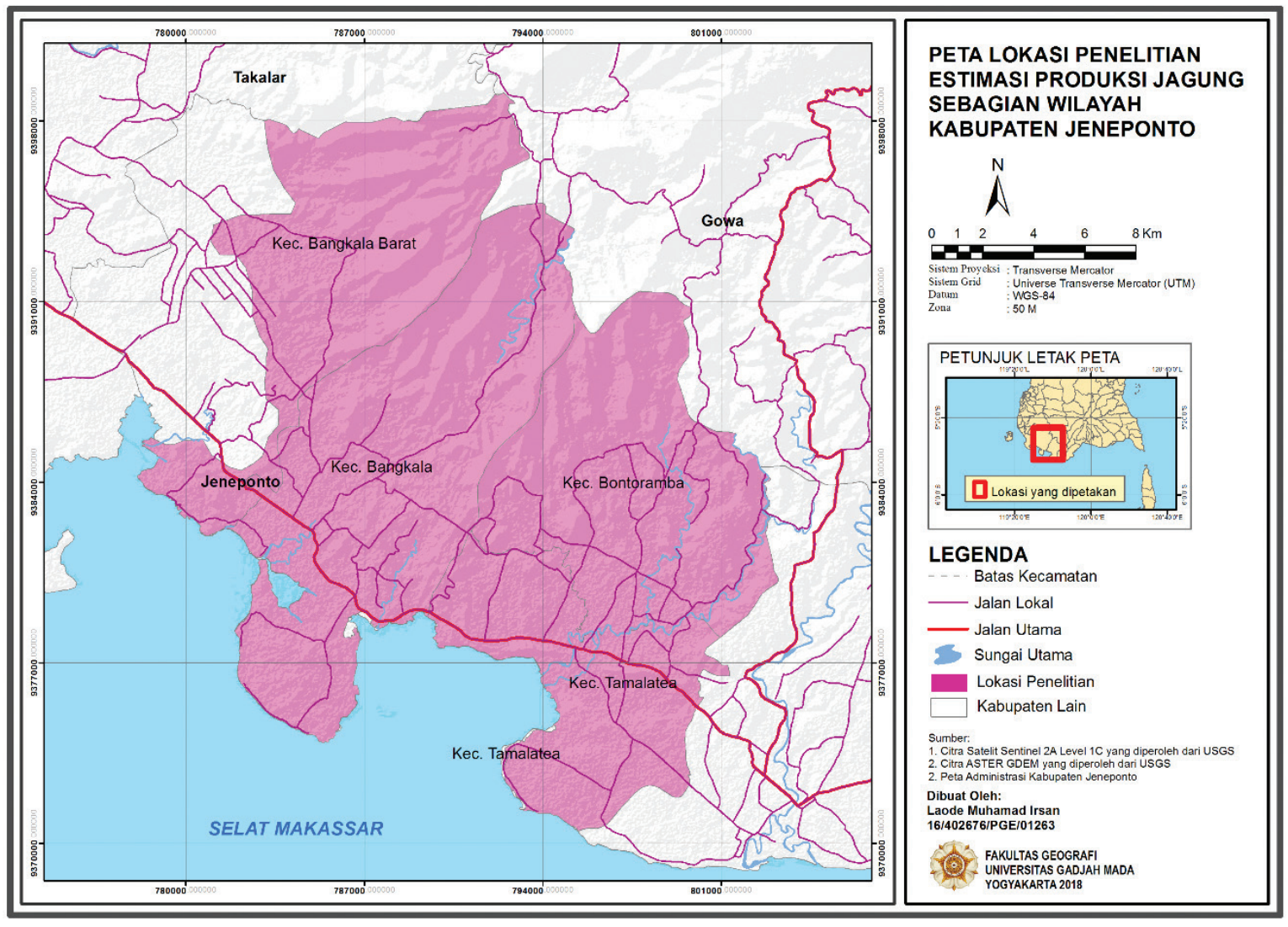

Gambar 1.

Peta lokasi penelitian 
Estimasi difokuskan pada jenis jagung produksi dengan jenis jagung hibrida yang memiliki varietas unggul. Keempat Kecamataan ini dipilih berdasarkan beberapa pertimbangan berikut: Pertama, kesesuain antara daerah penelitian dengan tujuan penelitian bahwa Kabupaten Jeneponto merupakan penghasil jagung terbesar di Provinsi Sulawesi Selatan sehingga, dinilai sesuai untuk melakukan estimasi produksi tanaman jagung. Selain itu, wilayah ini memiliki variasi medan atau wilayah yang cukup kompleks. Variasi wilayah tersebut merupakan salah satu variabel yang diperhitungkan dalam penyusunan model spasial untuk estimasi produksi tanaman jagung. Kedua, kesesuaian antara daerah kajian dengan ketersediaan citra penginderaan jauh yang ada.

Citra yang digunakan pada penelitian ini yaitu citra Sentinel 2A dengan resolusi temporal 10 hari. Jika dihitung dalam satu tahun jumlah perekaman yang diperoleh yaitu kurang lebih 35-36 kali artinya mampu menghaslkan 36 citra. Secara jumlah tentu ini sangat menguntungkan, tetapi faktanya untuk mendapatkan citra yang bebas dari gangguan sangat sulit. Penyebabnya adalah letak Indonesia yang berada di daerah tropis yang mana proses pembentukan awan sangat intensif ditambah lagi dengan kondisi daerah penelitian yang bergunung. Oleh karena ini, dalam penelitian ini lebih diutamakan ketersediaan citra yang relatif bebas dari gangguan dan kesesuaian musim tanam jagung daripada citra terbaru.

Landasan utama yang digunakan dalam pemlihan citra antara lain: (a) Karakteristik Citra Sentinel 2A, (b) Kesesuaian antara resolusi spasial dengan obyek kajian, (c) kesesuaian antara waktu perekaman citra dengan rotasi tanaman (jadwal tanam jagung).

a. Karakteristik Citra Sentinel 2A yaitu ditinjau dari resolusi spasialnya memiliki resolusi 10 meter, hal ini dapat berpengaruh pada tingkat kerincian informasi dan akan memberi dampak semakin tingginya ketelitian informasi pada citra tersebut. Dari segi karakteristik spektral citra sentinel 2A terdapat 13 saluran, tetapi yang digunakan dalam penelitian ini hanya empat yaitu: saluran dua (biru), saluran tiga (hijau, saluran empat (merah), dan saluran 8A (inframerah dekat). Pemilihan keempat saluran ini karena pada citra sentinel 2A saluran yang memiliki resolusi 10 meter hanya terdapat empat saluran.

b. Kesesuaian antara resolusi spasial dengan obyek kajian maksudnya dalam penelitian ini mengkaji tentang estimasi tanaman jagung dengan unit pengelolaaan terkecil adalah petak jagung. Satu petak artinya ukuran terkecil kepemilikan lahan oleh seorang petani yang dikelolah secara homogen. Akan tetapi, ukuran petak pada lahan jagung cenderung berfariasi tergantung pada kondisi medan dan kemampuan sosial-ekonomi petani. Ukuran petak lahan jagung minimal di wilayah kajian adalah $200-500 \mathrm{~m}^{2}$ yang tersebar diberbagai variasi medan, baik perbukitan maupun dataran. Resolusi citra yang digunakan yaitu $10 \mathrm{~m}$, atinya dalam $200 \mathrm{~m}^{2}$ terdapat 20 piksel sudah memenuhi syarat minimal yaitu sembilan piksel. Ukuran minimal petak jagung sudah sesuai dengan jenis citra yang digunakan yaitu Sentinel 2A.

Kesesuaian antara waktu perekaman dengan rotasi tanaman (kalender tanam). Perlu diketahui bahwa kesesuaian antara waktu perekaman citra dengan waktu tanam untuk estimasi produksi pertanian semusim merupakan suatu hal yang sangat penting. Tanaman jagung merupakan tanaman semusim yang berumur tiga sampai empat bulan mulai dari awal tanam sampai dengan waktu panen.

Menurut beberapa teori dan hasil penelitian menunjukan bahwa nilai spektral yang maksimal terjadi pada waktu dekat panen. Pada waktu inilah ideaalnya untuk sensor penginderaan jauh melakukan perekaman pada lahan pertanian. Akan tetapi, kenyataannya agak sulit mendapatkan citra yang sesuai dengan waktu maksimal pantulan spektral yang sebagian besar disebabkan oleh gangguan awan. Pada penelitian ini menggunakan citra sentinel 2A yang direkam pada tangal 20 Januari 2017, yang mana pada waktu tersebut umur jagung kurang lebih 60 
hari (2 bulan). Pada waktu ini umur jagung dinilai sudah masuk pada waktu ideal untuk perekaman citra karena memilki pantulan spektral yang tinggi.

Pemrosesan citra penginderaan jauh Sentinel 2A terlebih dahulu diawali dengan melakukan koreksi pada citra. Proses koreksi yang digunakan yaitu koreksi radiometrik (koreksi atmosferik). Koreksi geometrik pada penelitian ini tidak dilakukan karena citra sentinel 2A yang digunakan merupakan citra dengan level $1 \mathrm{C}$ bahwa pada level ini citra telah terkoreksi geometrik.

Koreksi atmosferik dilakukan untuk mengurangi kesalahan radiometrik yang disebabkan oleh gangguan atmosfer terutama seperti partikel debu, uap air, dan gas triatomik lainnya yang menyebabkan nilai piksel pada citra tidak mengambarkan nilai yang sebenarnya. Koreksi atmosferik dilakukan dalam tiga tahap dari mengubah nilai digital menuju nilai radian sampai pada nilai at surface reflectance dengan metode yang dikembangkan oleh Chavez (1996) yaitu Dark Object Subtraction (DOS).

Citra yang telah terkoreksi kemudian menjadi data input dalam melakukan pemetaan penggunaan lahan dan pemodelan estimasi produksi jagung. Pembuatan peta penutup lahan dilakukan dengan menggunakan metode maksimum likelihood. Metode klasifikasi ini digunakan dalam penelitian dengan dasar wahwa Klasifikasi maximum likelihood merupakan metode klasifikasi yang sangat baik bila dilengkapi training data yang akurat dan salah satu algoritma yang paling banyak digunakan dalam proses klasifikasi citra. Hasil dari penyusunan peta penutup lahan yang telah dibuat menjadi dasar dalam pembuatan peta penggunaan lahan. Proses klasifikasi dilakukan dengan beberapa tahap yaitu penyusunan komposit, pengambilan training area, dan klasifikasi terbimbing.

Metode transformasi citra yang digunakan dalam melakukan estimasi produksi tanaman jagung yaitu berdasarkan pendekatan spektral. Estimasi produksi dengan menggunakan pendekatan spektral dilakukan dengan penyusunan indeks vegetasi pada citra yang berfungsi meningkatkan kepekaan spekral citra dalam membaca obyek vegetasi dan menurunkan kepekaan spektal obyek nonvegetasi lainnya. Setelah penyusunan indeks dilakukan, maka dilakukan pembacaan nilai spektral pada titik-titik sampel yang telah ditentukan.

Penentuan sampel titik berdasarkan perimbangan bahwa piksel-piksel tersebut merepresentasikan tanaman pertanian khususnya jagung dan variasi nilai indeks yang ada pada citra tersebut. Indeks vegetasi yang digunakan dalam penelitian ini yaitu jenis indeks vegetasi empris atau indeks yang sudah umum digunakan dalam kajian vegetasi yakni NDVI, SAVI, MSAVI, TSAVI, EVI, dan ARVI.

Tabel 1.

Indeks vegetasi yang digunakan untuk estimasi produksi

\begin{tabular}{|c|c|c|c|}
\hline No & Indek Vegetasi & Formula/Persamaan & Keterangan \\
\hline 1 & $\begin{array}{l}\text { NDVI ( Normalised Difference } \\
\text { Vegetation Indeks) }\end{array}$ & $N D V I=\frac{I M D-M}{M D+M}$ & \multirow{6}{*}{$\begin{array}{ll}\text { M } & : \text { Merah } \\
\mathrm{B} & : \text { Biru } \\
\text { IMD } & : \text { Inframerah } \\
& \text { Dekat } \\
\mathrm{L} & : \text { 1-2s (NDVI) } \\
\mathrm{S} & : \text { Kemiringan } \\
& \text { garis tanah }\end{array}$} \\
\hline 2 & $\begin{array}{l}\text { SAVI (Soil Adjusted Vegetation } \\
\text { Index) }\end{array}$ & $S A V I=\frac{1,5 *(I M D-M)}{(I M D+M+0,5}$ & \\
\hline 3 & $\begin{array}{l}\text { MSAVI (Modified Soil } \\
\text { Adjusted Vegetation Indeks) }\end{array}$ & $M S A V I=\frac{(I M D)+M}{(I M D+M+L} x(1+L)$ & \\
\hline 4 & $\begin{array}{l}\text { TSAVI (Transformed Soil } \\
\text { Adjusted Vegetation Index) }\end{array}$ & $T S A V I=\frac{s(I M D-M)+a}{(a x M D+M)-(a x s+X x(1+\mathrm{s} 2))} x(1+L)$ & \\
\hline 5 & $\begin{array}{l}\text { EVI (Enhanced Vegetation } \\
\text { Indeks) }\end{array}$ & $E V I=\frac{2,5(I M D-M)}{1+I M D+6 M+7,5 B)}$ & \\
\hline 6 & $\begin{array}{l}\text { ARVI (Atmospherically } \\
\text { Resistance Vegetation Index) }\end{array}$ & $A R V I=\frac{(I M D+B)}{(I M D+B)}$ & \\
\hline
\end{tabular}



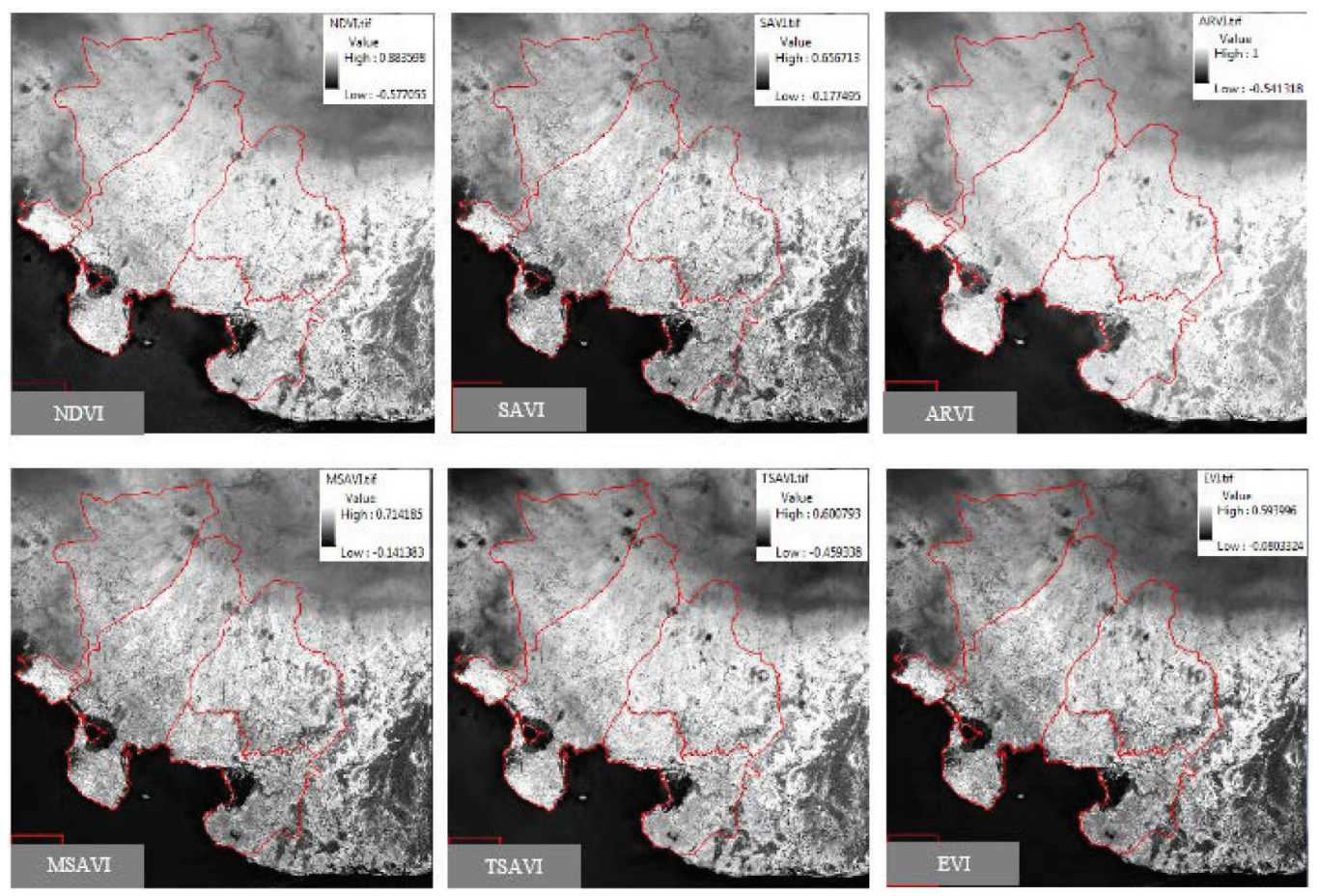

Gambar 2.

Citra Sentinel 2A setelah dilakukan proses Indeks

Citra sentinel 2A yang telah dilakukan proses koreksi radiometrik dan indeks vegetasi kemudian digunakan untuk pemodelan estimasi produksi berdasarkan data yang diperoleh dari lapangan. Jumlah sampel yang digunakan yaitu sebanyak 60 sampel yang terdiri dari 33 sampel untuk model dan 25 sampel untuk uji akurasi. Metode pengambilan sampel yakni dengan melakukan wawancara langsung dengan petani jagung pada setiap titik sampel. Pengambilan sampel dengan metode pengukuran langsung di lapangan tidak dilakukan karena citra sentinel 2A yang digunakan yaitu tahun 2017 sehingga tidak dimungkinkan untuk melakukan pengukuran langsung. Hasil dari sampel yang dikumpulkan menjadi input dalam membuat model estimasi produksi jagung.

\section{HASIL DAN PEMBAHASAN Pemetaan Penggunaan Lahan}

Dari hasil interpretasi dan klasifikasi citra Sentinel 2A kemudian dihasilkan sembilan kelas penggunaan lahan yaitu awan, bayangan awan, pemukiman, lahan terbuka, hutan+semak, perkebunan, sawah, tambak, dan tubuh air. Sebenarnya jika dilihat awan dan bayangan awan bukan merupakan kelas penggunaan lahan, tetapi ikut dimasukan dan tidak akan digunakan dalam perhitungan estimasi produksi. Data lapangan merupakan langkah untuk memastikan kebenaran penggunaan lahan yang telah diintrepretasi sebelumnya dengan menggunakan citra sentinel 2A pada lokasi penelitian. Lokasi pengecekan dilakukan sesuai titik sampel yang telah disebar pada setiap jenis penggunaan lahan. Jumlah titik sampel yang dipastikan yaitu sebanyak 51 titik sampel yang tersebar secara random dengan mewakili semua jenis penggunaan lahan. Jumlah titik setiap kelas berbeda-beda hal ini disesuaikan dengan luasan kelas dan karakteristik wilayahnya.

Setelah pengecekan lapangan selesai maka langkah selanjutnya yaitu melakukan perbaikan pada peta tentatif atau biasa disebut reinterpretasi. Perbaikan dilakukan pada kelas penggunaan lahan yang tidak sesuai dengan kondisi sebenarnya di lapangan. Terdapat beberapa kelas yang tidak sesuai dengan kondisi sebenarnya yaitu kelas penggunaan lahan lahan terbuka, semak dan hutan, perkebunan, dan sawah. Kelas yang memiliki kesalahan terbanyak adalah perkebunan dan sawah, dan lahan terbuka dan sawah. 


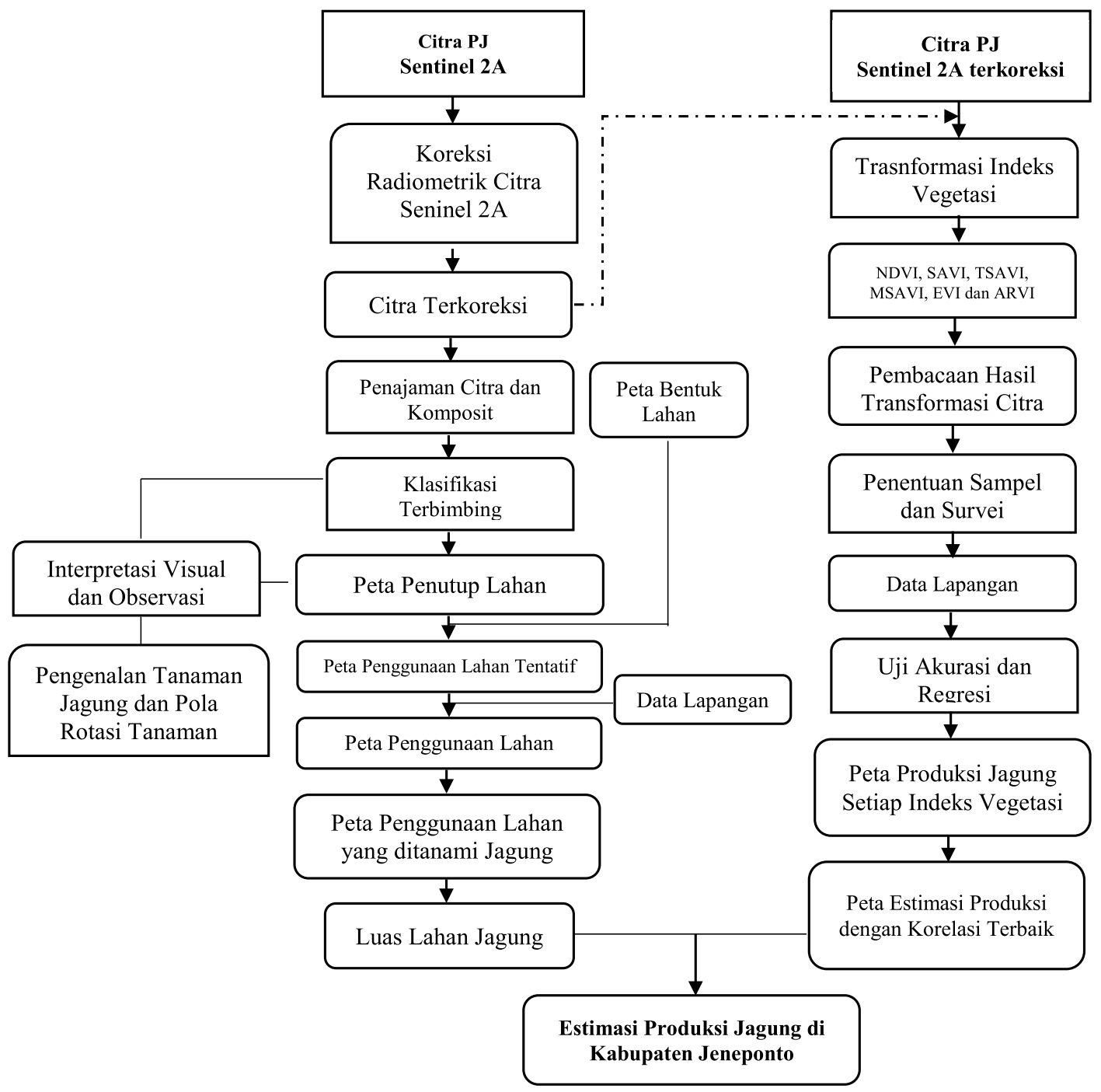

Gambar 3.

Diagram alir penelitian

Tabel 2.

Data hasil matrix confusion penggunaan lahan

\begin{tabular}{|c|c|c|c|c|c|c|c|c|c|c|c|c|c|}
\hline \multirow{2}{*}{\multicolumn{2}{|c|}{$\begin{array}{c}\text { MATRIX KONFUSI } \\
\text { PL-1 }\end{array}$}} & \multicolumn{12}{|c|}{ Hasil Interpretasi Citra Sentinel 2A } \\
\hline & & PL-2 & PL-3 & PL-4 & PL-5 & PL-6 & PL-7 & PL-8 & PL-9 & Total & User & Error Comossion & \\
\hline \multirow{12}{*}{ 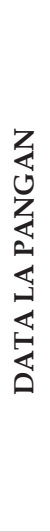 } & PL-1 & 0 & 0 & 0 & 0 & 0 & 0 & 0 & 0 & 0 & 0 & 0 & - \\
\hline & PL-2 & 0 & 0 & 0 & 0 & 0 & 0 & 0 & 0 & 0 & 0 & 0 & - \\
\hline & PL-3 & 0 & 0 & 6 & 0 & 0 & 0 & 0 & 0 & 0 & 6 & 1.00 & $100 \%$ \\
\hline & PL-4 & 0 & 0 & 0 & 2 & 0 & 0 & 0 & 0 & 0 & 2 & 1.00 & 0.00 \\
\hline & PL-5 & 0 & 0 & 0 & 0 & 3 & 0 & 0 & 0 & 0 & 3 & 1.00 & 0.00 \\
\hline & PL-6 & 0 & 0 & 0 & 0 & 1 & 17 & 1 & 0 & 0 & 19 & 0.89 & 11.00 \\
\hline & PL-7 & 0 & 0 & 0 & 1 & 0 & 2 & 11 & 0 & 0 & 14 & 0.78 & 21.00 \\
\hline & PL-8 & 0 & 0 & 0 & 0 & 0 & 0 & 0 & 5 & 0 & 5 & 1.00 & 100.00 \\
\hline & PL-9 & 0 & 0 & 0 & 0 & 0 & 0 & 0 & 0 & 2 & 2 & 1.00 & 100.00 \\
\hline & Total & 0 & 0 & 6 & 3 & 4 & 19 & 12 & 5 & 2 & 51 & & 46 \\
\hline & Producer Accruracy & - & - & 1.00 & 67.00 & 75.00 & 89.00 & 92.00 & 100 & 100 & \multicolumn{2}{|c|}{ Overall Accuracy } & 90.10 \\
\hline & Error Omission & - & - & 100 & 33.00 & 25.00 & 11.00 & 8.00 & 100 & 100 & \multicolumn{2}{|c|}{ Kappa } & 0.91 \\
\hline
\end{tabular}


Dari hasil uji akurasi pada tabel 2 menunjukan bahwa tingkat akurasi pemetaan penggunaan lahan dengan menggunakan citra Sentinel 2A mencapai 90\%. Jika kita lihat berdasarkan standar, maka nilai akurasi ini sudah masuk pada kategori sedang yaitu antara 90\% - 94\%. Beberapa kelas yang tidak memiliki akurasi 100\% terdapat pada kelas perkebunan, sawah, dan lahan terbuka. Hal disebabkan oleh beberapa faktor antara lain kesamaan ciri antara kenampakan sawah dan perkebunan yakni sama-sama memiliki petak sehingga menyebabkan adanya kesalahan interpretasi saat melakukan training area.

Data yang telah diperoleh dari hasil pengecekan di lapangan menjadi patokan dalam melakukan perbaikan peta penggunaan lahan. Setiap kelas penggunaan lahan yang berbeda dengan kondisi sebenarnya kemudian dijadikan pertimbangan dalam proses reinterpretasi. Peta berikut ini Gambar 3 menunjukan hasil reinterpretasi dan generalisasi kelas penggunaan lahan pada citra Sentinel 2A. Sedangkan pada Tabel 3 berikut ini menunjukan luas masingmasing penggunaan lahan di wilayah kajian.

Tabel 3

luas masing-masing penggunaan lahan

\begin{tabular}{lll}
\hline No & Penggunaan lahan & Luas Lahan (ha) \\
\hline 1 & Pekebuanan Jagung & $19.210,83$ \\
\hline 2 & Tambak & $1.406,41$ \\
\hline 3 & Awan & 576,24 \\
\hline 4 & Pemukiman & $2.138,70$ \\
\hline 5 & Lahan terbuka & 335,93 \\
\hline 6 & Sawah & $7.624,76$ \\
\hline 7 & Hutan dan Semak & $7.387,72$ \\
\hline
\end{tabular}

(Sumber: Hasil pengolahan data, 2017)

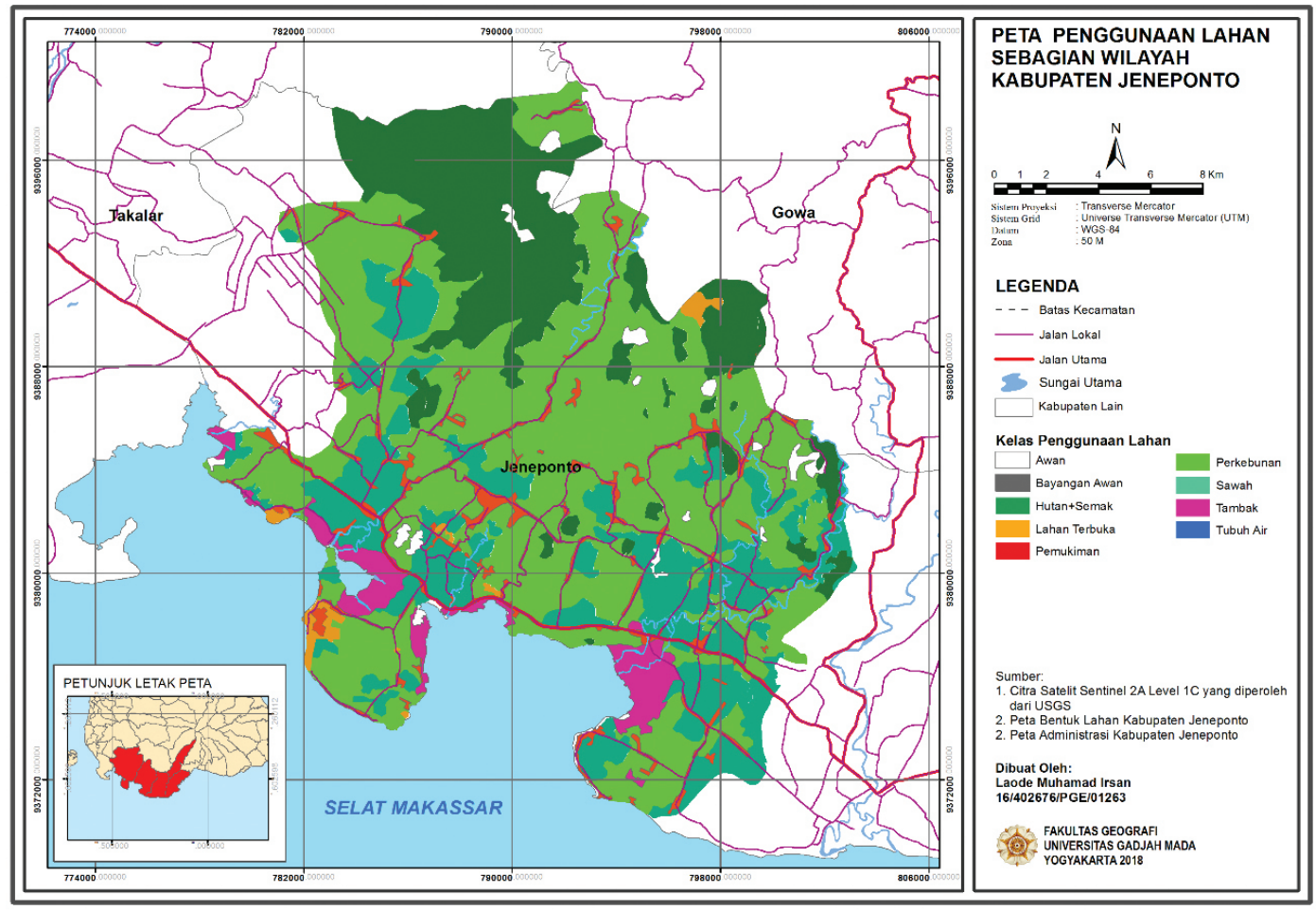

Gambar 4.

Peta penggunaan lahan

\section{Pemodelan Spasial Citra Sentinel 2A}

Citra sentinel 2A yang telah dilakukan proses koreksi radiometrik dan indeks vegetasi kemudian digunakan untuk pemodelan estimasi produksi berdasarkan data yang diperoleh dari lapangan Pada. Indeks vegetasi yang digunakan dalam penelitian ini yaitu jenis indeks vegetasi empris atau indeks yang sudah umum digunakan dalam kajian vegetasi yakni NDVI, SAVI, MSAVI, TSAVI, EVI, dan ARVI. 
Hasil pemodelan tersebut kemudian dlakukan validasi dengan data jumlah produksi di lapangan. Data yang telah diperoleh dari lapangan kemudian dilakukan uji normalitas terlebih dahulu. Tujuanya untuk mengetahui apakah data yang digunakan normal atau tidak, syarat dari suatu data dapat digunakan untuk proses korelasi dan regresi harus normal minimal memiliki nilai signifikansi sebesar 0,05 .
Metode yang digunakan untuk uji normalitas yaitu Shapiro-Wilk karena jumlah data kurang dari 50 sampel. Hasil uji normalitas sampel menunjukan nilai signifikasi yang cukup baik yaitu 0,09 artinya data sudah bisa digunakan untuk uji korelasi dan regresi. Data sampel untuk membuat model estimasi yaitu 35 titik dilakukan analisis korelasi dan regresi. Metode yang digunakan yaitu korelasi linear dengan menggunakan program SPSS 22.

Tabel 4.

Hasil uji korelasi dan regresi indeks vegetasi dengan jumlah produksi jagung di lapangan

\begin{tabular}{llllll}
\hline No & \multicolumn{1}{c}{ Input } & Normalitas Data & Model Regresi & $r$ & $R^{2}$ \\
\hline 1 & NDVI & Normal & Linear & 0.72 & 0.51 \\
\hline 2 & SAVI & Normal & Linear & 0.70 & 0.49 \\
\hline 3 & MSAVI & Normal & Linear & 0.71 & 0.50 \\
\hline 4 & TSAVI & Normal & Linear & 0.71 & 0.51 \\
\hline 5 & EVI & Normal & Linear & 0.74 & 0.55 \\
\hline 6 & ARVI & Normal & Linear & 0.62 & 0.38 \\
\hline
\end{tabular}

(Sumber: Hasil Pengolahan Data, 2018)
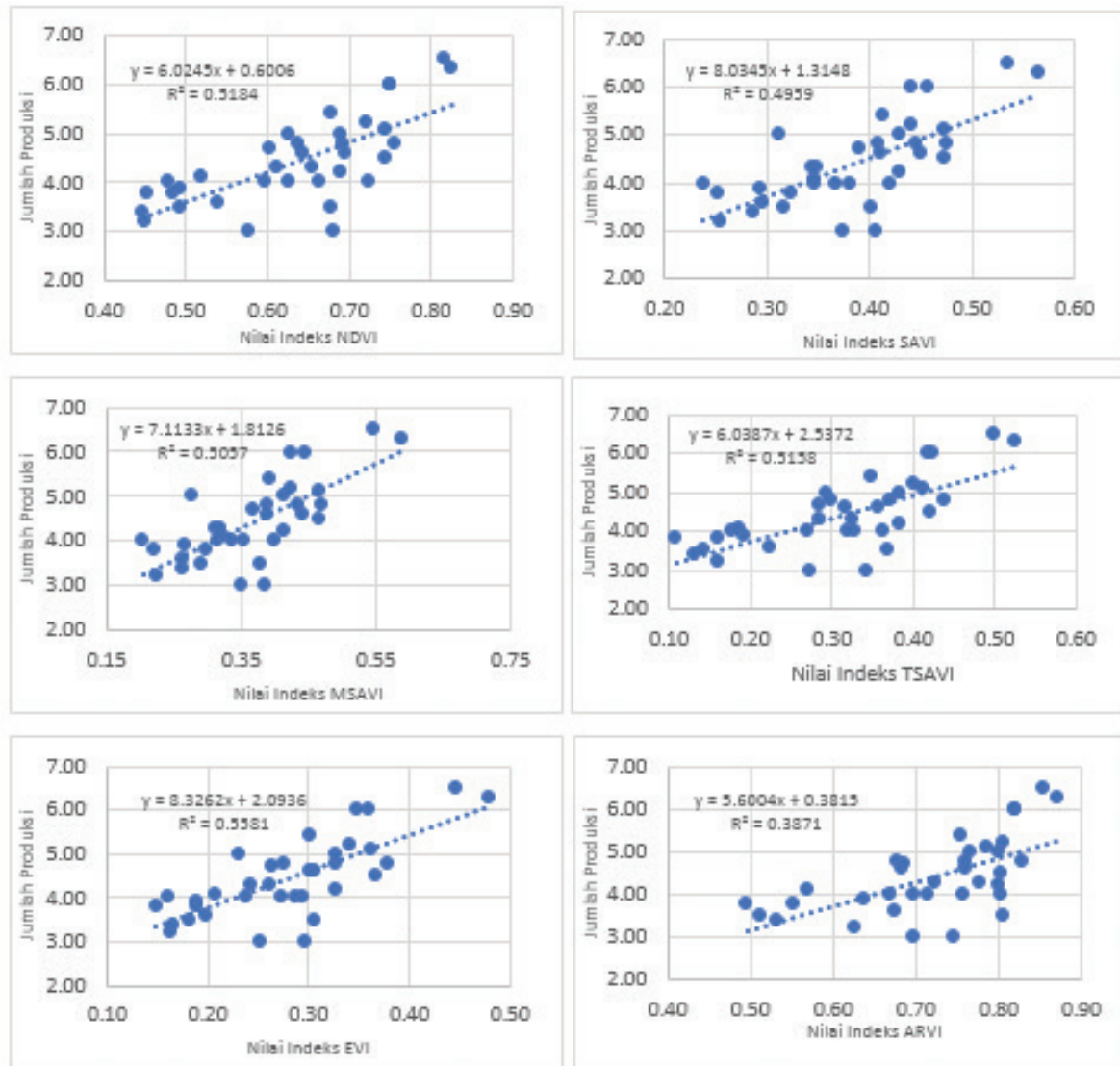

Gambar 5.

Grafik hasil regresi masing-masing indeks 
Hasil analisis menujukan bahwa korelasi dan regresi terbaik yaitu indeks vegetasi EVI dengan nilai $r=0,74$ dan nilai $\mathrm{R}^{2}=0,55$. Hal ini didukung oleh kemampuan indeks vegetasi EVI dalam mengurangi pengaruh gangguan atmosfer sehingga meningkatkan sensivitas biomassa. Sedangkan korelasi dan regresi terendah yaitu indeks vegetasi ARVI dengan nilai $r=0,62$ dan nilai $\mathbf{R}^{2}=0,38$. Nilai tersebut menunjukan bahwa terdapat hubungan positif antara nilai indeks vegetasi dengan jumlah produksi karena semakin besar nilai indeks vegetasi diikuti pula kenaikan jumlah produksi dan sebaliknya.
Pemodelan estimasi produksi jagung menggunakan semua jenis indeks yaitu (NDVI, SAVI, MSAVI, TSAVI, EVI, dan ARVI karena memiliki korelasi yang cukup baik. Dari semua indeks kemudian dibandingkan untuk mengetahui model indeks terbaik yang diketahui dari uji akurasi yang memiliki nilai standar eror (SE) paling rendah pada setiap modelnya. Dari hasil uji regresi kemudian didapatkan rumus $Y$ pada setiap jenis indeksnya. Pada tabel 5 berikut menunjukan rumus regresi pada masing-masing indeks untuk mengestimasi jumlah produksi jagung.

Tabel 5.

rumus regresi pada masing-masing indeks vegetasi

\begin{tabular}{lllllll}
\hline No & Input & $\begin{array}{c}\text { Nilai a } \\
\text { (Konstanta) }\end{array}$ & Nilai b & $\begin{array}{c}\text { Indeks } \\
\text { Vegetasi (X) }\end{array}$ & \multicolumn{1}{c}{ Rumus $\mathbf{~}$} & Jumlah Produksi \\
\hline 1 & NDVI & 0.05 & 6.024 & NDVI (b1) & $\mathrm{Y}=0.601+\left(6.024^{*} \mathrm{~b} 1\right)$ & $179.429,13$ \\
\hline 2 & SAVI & 0.05 & 8.035 & SAVI (b2) & $\mathrm{Y}=1.315+\left(8.035^{*} \mathrm{~b} 2\right)$ & $179.044,91$ \\
\hline 3 & MSAVI & 0.05 & 7.113 & MSAVI (b3) & $\mathrm{Y}=1.813+\left(7.113^{*} \mathrm{~b} 3\right)$ & 178.660 .9 \\
\hline 4 & TSAVI & 0.05 & 6.039 & TSAVI (b4) & $\mathrm{Y}=2.537+\left(6.039^{*} \mathrm{~b} 4\right)$ & 179.429 .13 \\
\hline 5 & EVI & 0.05 & 8.326 & EVI (b5) & $\mathrm{Y}=2.094+\left(8.326^{*} \mathrm{~b} 5\right)$ & 178.660 .69 \\
\hline 6 & ARVI & 0.05 & 5.600 & ARVI (b6) & $\mathrm{Y}=0.386+\left(5.60^{*} \mathrm{~b} 6\right)$ & 177.892 .26 \\
\hline
\end{tabular}

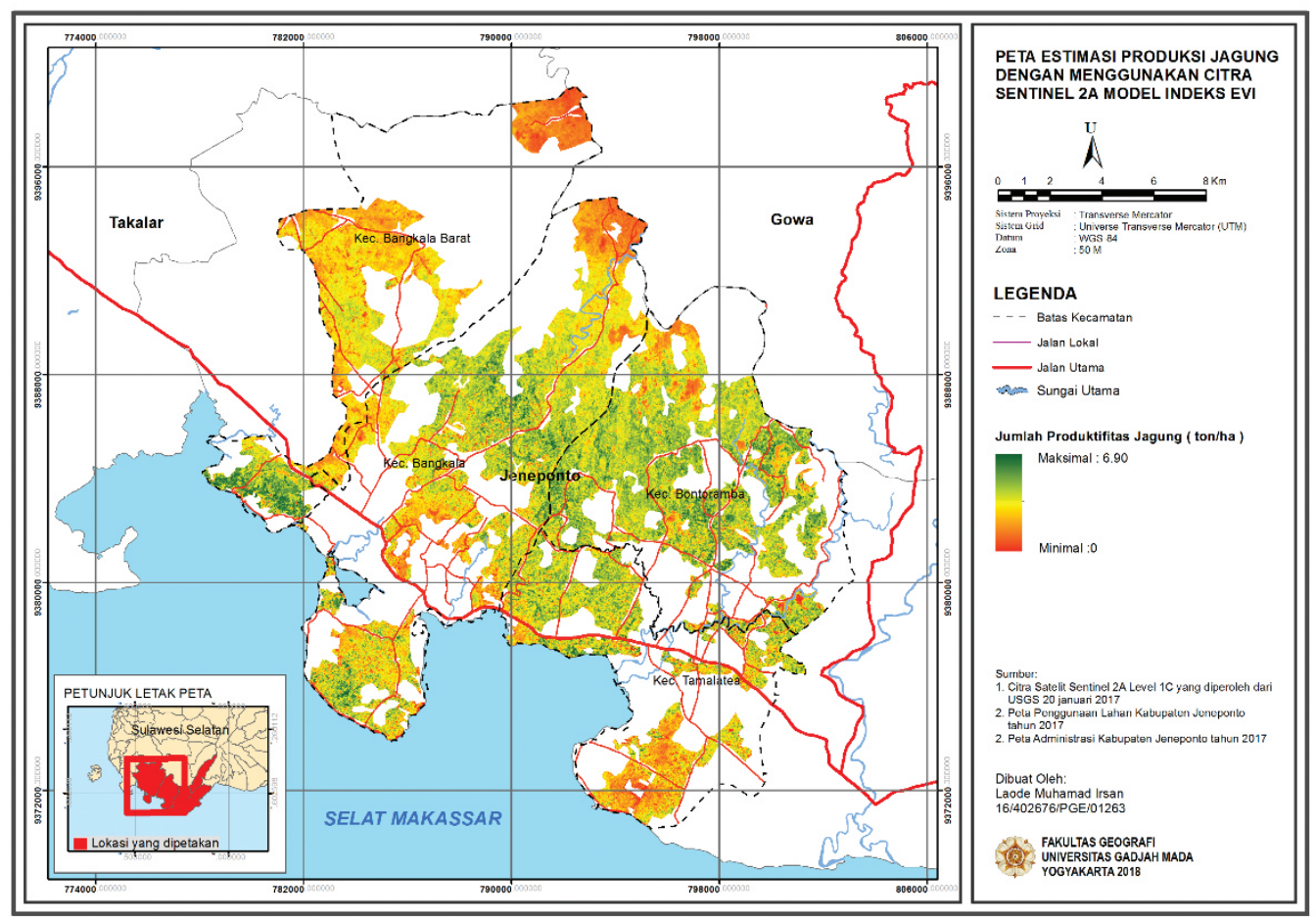

Gambar 6.

Peta estimasi produksi terbaik (model indeks EVI) 
Uji akurasi model estimasi produksi jagung pada lokasi penelitian dilakukan dengan membandingkan jumlah produksi hasil estimasi dengan jumlah produksi pada 25 titik sampel di lapangan. Metode uji akurasi menggunakan Standar Eror (SE) yang hasil analisisnya dinyatakan dalam bentuk nilai SE.

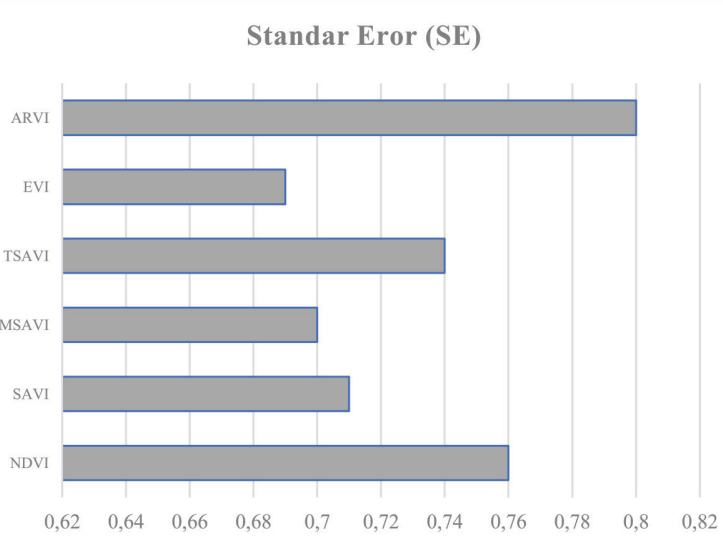

Gambar 7.

Perbandingan nilai SE setiap model indeks

Berdasarkan hasil uji akurasi model estimasi produksijagung dengan menggunakan data lapangan, model estimasi indeks EVI memiliki nilai SE yang paling rendah yaitu 0.69 dengan jumlah produksi sebanyak 178.660,69 ton. Selisih antara estimasi produksi yang tertinggi dengan terendah yaitu $36.870,88$ ton. Sedangkan untuk setiap kecamatan, jumlah produksi terbanyak terdapat pada Kecamatan Bangkala yaitu $65.374,55$ ton dan jumlah produksi terendah terdapat pada Kecamatan Tamalatea dengan jumlah produksi sebanyak $28.503,55$ ton. Selisih yang cukup tinggi pada setiap hasil estimasi produksi disebabkan oleh perbedaan indeks vegetasi yang digunakan, dimana setiap indeks memiliki metode yang berbeda dalam pembancaan nilai piksel. Faktor lain yaitu waktu tanam jagung yang tidak serentak mempengaruhi tingginya variasi nilai piksel pada wilayah kajian.

\section{SIMPULAN}

Citra penginderaan jauh Sentinel 2A dapat digunakan untuk memperoleh informasi lahan pertanian khususnya jagung dengan menggunakan pendekatan spektral baik dalam pementaan penggunaan lahan maupun estimasi produksi jagung. Hasil klasifikasi penggunaan lahan di sebagaian wilayah Kabupaten Jeneponto menghasilkan ketelitian interpretasi 90,01 \%. Akurasi ini masuk pada kategori akurasi yang dapat diterima (lebih dari $85 \%$ ) atau masuk kategori sedang dengan rentang standar nilai akurasi antara 90 - $95 \%$.

Sedangkan estimasi produksi dengan menggunakan pendekatan spektral yakni transformasi indeks vegetasi menunjukan korelasi indeks dengan produksi di lapangan yaitu $74 \%$. Dari 6 model indeks vegetasi (NDVI, SAVI, MSAVI, TSAVI, EVI, dan ARVI) akurasi terbaik ditunjukan oleh model indeks EVI dengan nilai Standar Eror 0,61. Sedangkan akurasi yang terendah yaitu model indeks ARVI dengan nilai standar eror 0.80 .

\section{DAFTAR PUSTAKA}

Badan Pusat Statistik. 2016. Kabupaten Jeneponto Dalam Angka. BPS Kabupaten Jeneponto. Tamalatea.

Chavez, P. S. 1996. Image-based atmospheric corrections-revisited and improved. Photogrammetric Engineering $\mathcal{E}$ Remote Sensing, 62(9), 1025-1036.

Harahap, I.Y., Winarna, dan E.S. Sutarta. 2000. Produktivitas Tanaman Kelapa Sawit: Tinjauan dari Aspek Tanah dan Iklim. Pertemuan Teknis Kelapa Sawit I. Medan: Pusat Penelitian Kelapa Sawit. 25-26 April 2000.

Howard, John A. 1991. Remote Sensing of Forest Resources: Theory and Application: London: Champman and Hall.

Jin, X., Ma, J., Zidan, W., dan Kaishan, S. 2015. Estimation of Maize Residue Cover Using Landsat-8 OLI Image Spectral Information and Textural Features. Northeast Institute of Geography and Agroecology, Chinese Academy of Sciences, Changchun. China.

Murti, S. H. 2014. Pemodelan Spasial Untuk Estimasi Produksi Padi dan Tembakau Berdasarkan Citra Muliresolusi (Kasus Untuk Produksi Padi di 
Kabupaten Wonosobo dan Sragen, serta Produksi Tembakau di Kabupaten Temanggung, Provinsi Jawa Tengah), Disestasi, Universitas Gajah Mada. Yogyakarta.

Kementrian Pertanian RI. 2015. Statistik Pertanian 2015. Jakarta: Pusat Data dan Sistem Informasi Pertanian.

Kementrian Pertanian RI. 2016. Outlook Jagung. Pusat Data dan Sistem Informasi Pertanian. Jakarta.

Martono, D. N. 2008. Aplikasi Teknologi Penginderaan Jauh Dan Uji Validasinya Untuk Deteksi Penyebaran Lahan Sawah dan Penggunaan/ Penutupan Lahan. Seminar Nasional Aplikasi Teknologi Informasi (SNATI) Yogyakarta, 47-56.

Rueda-Ayala, V., Kunapuli,S., dan Maiguashca, J. 2015. Development of Yield Prediction Models In The Maise Crop Using Spectral Data For Precision Agriculture Aplication. Ecuador Es Calidad, 2(1):16-22.
Skakun, S., Vermote. E., Jeans, C. R., dan Belen F. 2017. Cobined Use of Landsat-8 and Sentinel-2A Images for Winter Crop Mapping and Winter Wheat Yield Assesment at Regional Scale, AIMS Geosciences, 3 (2): 163-186.

Soria, R. J., Y. Fernandes dan Rebeca G. R. 2004. Methodology for prediction of corn yield using remote sensing satellite data in Central Mexico, Meksiko: INIFAP.

Sugiyono. 2014. Statistik Untuk Penelitian. Bandung: Alfabeta.

Wahyunto, W., dan Bambang, H. 2006. Pendugaan Produktivitas Tanaman Padi Sawah Melalui Analisis Citra Satelit. Bogor: Peneliti Balai Besar Litbang Sumberdaya Lahan Pertanian. 